\title{
Deutiches Lejebud
}

fat

\section{böbere Mädd)enโdulen $\left(\mathfrak{E}_{\mathfrak{y} z \mathfrak{z} \mathfrak{n})}\right.$}

oon

Rarl Selfel.

\author{
Bierter Eetl. \\ Gedjite Rlafie.
}

Eifte 2uflage.

\section{Bonn 1914.}

X. Marcus und $\mathfrak{E}$. Webers DerTag- 
